\title{
Statyba
}

\section{TECHNOLOGY OF COMPUTATION OF REINFORCED CONCRETE STRUCTURES}

\section{A. Jurkša}

To cite this article: A. Jurkša (2001) TECHNOLOGY OF COMPUTATION OF REINFORCED CONCRETE STRUCTURES, Statyba, 7:6, 419-424, DOI: 10.1080/13921525.2001.10531767

To link to this article: https://doi.org/10.1080/13921525.2001.10531767

册 Published online: 30 Jul 2012.

Submit your article to this journal 5

Џ Article views: 166 


\section{GELŽBETONINIU KONSTRUKCIJŲ ARMATŪROS AUTOMATIZUOTO SKAIČIAVIMO TECHNOLOGIJA}

\section{A. Jurkša}

Vilniaus Gedimino technikos universitetas

\section{Ivadas}

Statybos konstrukcijoms automatizuotai skaičiuoti Lietuvoje dažniausiai taikoma pasaulyje plačiai paplitusi ir pripažinta STAAD.Pro baigtinių elementų metodo kompiuterinè programa [1]. Dèl didelès LIRA-Windows programos kainos ją Lietuvos projektuotojai naudoja rečiau [2]. STAAD.Pro ir LIRA-Windows programos turi modulius gelžbetoninių konstrukcijų armatūrai skaičiuoti pagal Lietuvoje galiojančias statybos normas ir taisykles [3]. Straipsnio autorius yra sukaupęs nemenką sudetingy konstrukciju automatizuoto skaičiavimo praktinę patirti naudojant ivairias baigtinių elementu metodo kompiuterines programas, tarp jų STAAD.Pro, LIRA-Windows ir COSMOS/M [4]. Nustatyta, kad sudėtingu konstrukciju skaičiavimams STAAD.Pro ir LIRA-Windows programas naudoti neretai būna neracionalu, nes reikia daug galingesnių modeliavimo priemoniu ir didesnio skaičiavimo greičio. Nemenkas STAAD.Pro programos trūkumas yra tas, kad ji iki šiol neturi armavimo intensyvumy grafinio vaizdavimo priemoniu. COS$M O S / M$ programos pagrindiniai privalumai - puikios modeliavimo bei analizès priemonès ir nepaprastai didelis atliekamų skaičiavimy greitis, tačiau COSMOS $M$ iki šiol neturejo gelžbetoninių konstrukcijų armatūros apskaičiavimo modulių. Atsižvelgdamas i Lietuvos konstruktoriu poreikius, straipsnio autorius šią problemą išsprendè - sukūrè paprastojo gelžbetonio plokščių, sienu̧ kevalų, sijų ir kolonų armatūros kompiuterinio skaičiavimo pažangią technologiją naudojantis analizès su COSMOS/M programa rezultatais. Armatūros skaičiavimai atliekami ivvertinant stiprumo ir pleišètumo reikalavimus pagal Lietuvoje galiojančias statybos normas ir taisykles [3]. Svarbi šios technologijos ypatybè yra ta, kad plokščiu, sienų ir kevalu armatūros kompiuterinio skaičiavimo rezultatai pateikiami grafiškai. Armavimo intensyvumų grafinio vaizdavimo priemonę autorius sukūrè pasinaudojęs COSMOS/M programos galimybèmis ir informacija, pateikta straipsniuose $[5,6]$. Sukurta gelžbetoninių konstrukcijų automatizuoto skaičiavimo technologija sèkmingai taikoma Lietuvoje sprendžiant sudètingas gelžbetoniniu konstrukcijų projektavimo ir stiprinimo problemas.

Sukurtą armatūros skaičiavimo technologiją autorius taikè skaičiuodamas daugelị itin sudètingu konstrukciju. Toms pačioms problemoms spręsti buvo naudotos ir kitos minètos kompiuterinès programos [1, 2]. Nustatyta, kad, naudojant programą COSMOS/M ir taikant autoriaus sukurtą technologiją, sudėtingų konstrukcijų modeliavima, analizę ir gelžbetoniniu konstrukcijų armatūros skaičiavimus galima pagreitinti net iki 20 ir daugiau kartų. Labai svarbu, kad, taikant šią technologija, praktiškai nepasitaiko tokių atveju, kai konstrukcijas būna sudetinga teisingai sumodeliuoti ir apskaičiuoti.

\section{Gelžbetoninių plokščių, sienụ ir kevalų armatūros skaiciavimo technologija}

Gelžbetoniniụ plokščių, sienų ir kevalų simetriško arba nesimetriško armavimo intensyvumams apskaičiuoti straipsnio autorius sukūrè kompiuterinių programu COSARM ir COSMAX kompleksa. Rezultatai vaizduojami grafiškai. Armavimo linkmes galima pasirinkti laisvai. Su COSMOS/M programa sudaromas konstrukcijos kompiuterinis modelis ir apkrovų variantai, kurių bent viename pateikiamos tik nuolatinès ir ilgalaikès apkrovos. Kiti apkrovų variantai, be laikinų apkrovu, būtinai privalo turèti nuolatines ir ilgalaikes apkrovas. Apkrovų reikšmès - skaičiuojamosios. Atlikus analizę, COSMOS/M programos priemonèmis sukuriami ịrašai, kuriuose pateikiamos visos konstrukcijos arba jos pasirinktos dalies ittempimų baigtiniụ elementų mazguose 
reikšmès. Sudarant ịtempimų reikšmių ịrašus pasirenkama ta koordinačių sistema, kurios dviejų ašiụ linkmès sutampa su armavimo linkmėmis. Kiekvieną apkrovu variantą atitinka du įtempimų įrašai - elementų viršuje ir apačioje. Turint itempimu irašus, su COSARM programa skaičiuojami kiekvieną apkrovu variantą atitinkantys armavimo intensyvumai mazguose. COSARM programa nuskaito ne tik itempimų irašuose esančią infor- maciją, bet ir du papildomus ịrašus, kuriụ vardai yra fiksuoti: D.DAT ir INPUT.ARM. 1 lentelèje nurodytu eiliškumu $D . D A T$ ịraše pateikiamos parametrų reikšmès. INPUT.ARM ịrǎse pateikiama tokia informacija: simetriško ar nesimetriško armavimo kodas, armatūros skaičiavimo pobūdžio kodas (galima atsižvelgti i svarbiausius itempimus arba îvertinti pasirinktomis armavimo linkmèmis orientuotus normalinius itempimus), ivertinamy

1 lentelè. Parametrai D.DAT ịraše

Table 1. Parameters in D.DAT file

\begin{tabular}{|c|c|c|c|}
\hline $\begin{array}{l}\text { Eil. } \\
\text { Nr. }\end{array}$ & Parametras & Dimensija & Paaiškinimas \\
\hline 1 & $K L A$ & - & $\begin{array}{l}\text { Sveikasis skaičius, rodantis armatūros klasę, pavyzdžiui, } 3 \text {, jeigu armatūros klasè } \\
\text { yra } A-I I I\end{array}$ \\
\hline 2 & $A B$ & $\mathrm{MPa}$ & Dešimtainis skaičius, rodantis betono gniuždymo klasę, pavyzdžiui, 22,5 \\
\hline 3 & $R S$ & $M P a$ & $\begin{array}{l}\text { Armatūros projektinis stipris, ivertinus visus darbo sąlygų koeficientus (dešimtainis } \\
\text { skaičius) }\end{array}$ \\
\hline 4 & $R I 2$ & $M P a$ & Armatūros charakteringasis stipris (dešimtainis skaičius) \\
\hline 5 & ES & $\mathrm{MPa}$ & Armatūros tamprumo modulis (dešimtainis skaičius) \\
\hline 6 & $D D 1$ & $m m$ & Pirmosios linkmès armatūros strypų skersmuo (dešimtainis skaičius) \\
\hline 7 & DD2 & $m m$ & Antrosios linkmės armatūros strypų skersmuo (dešimtainis skaičius) \\
\hline 8 & $R B$ & $M P a$ & $\begin{array}{l}\text { Betono prizmių projektinis gniuždymo stipris, ịvertinus visus darbo sąlygų } \\
\text { koeficientus, tarp jų koeficientą } \gamma_{b 2} \text { (dešimtainis skaičius) }\end{array}$ \\
\hline 9 & $R P R 2$ & $M P a$ & Betono prizmių charakteringasis gniuždymo stipris (dešimtainis skaičius) \\
\hline 10 & $R T 2$ & $M P a$ & Betono charakteringasis tempimo stipris (dešimtainis skaičius) \\
\hline 11 & $E B$ & $M P a$ & Betono pradinis tamprumo modulis (dešimtainis skaičius) \\
\hline 12 & GAM2 & - & Betono darbo sąlygų koeficientas $\gamma_{b 2}$ (dešimtainis skaičius) \\
\hline 13 & $H$ & $m$ & Baigtinių elementų storis (dešimtainis skaičius) \\
\hline 14 & $P A$ & $m$ & $\begin{array}{l}\text { Apatinejje zonoje esančios pirmosios linkmès armatūros strypų centro atstumas iki } \\
\text { elemento artimiausio kraštinio sluoksnio (dešimtainis skaičius) }\end{array}$ \\
\hline 15 & $P A 1$ & $m$ & $\begin{array}{l}\text { Viršutinèje zonoje esančios pirmosios linkmés armatūros strypu centro atstumas iki } \\
\text { elemento artimiausio kraštinio sluoksnio (dešimtainis skaičius) }\end{array}$ \\
\hline 16 & $A A$ & $m$ & $\begin{array}{l}\text { Apatinèje zonoje esančios antrosios linkmės armatūros strypu centro atstumas iki } \\
\text { elemento artimiausio kraštinio sluoksnio (dešimtainis skaičius) }\end{array}$ \\
\hline 17 & $A A 1$ & $m$ & $\begin{array}{l}\text { Viršutinëje zonoje esančios antrosios linkmès armatūros strypų centro atstumas iki } \\
\text { elemento artimiausio kraštinio sluoksnio (dešimtainis skaičius) }\end{array}$ \\
\hline 18 & $A L O I$ & $m$ & Elementụ skaičiuojamasis ilgis pirmąja linkme (dešimtainis skaičius) \\
\hline 19 & ALO2 & $m$ & Elementų skaičiuojamasis ilgis antraja linkme (dešimtainis skaičius) \\
\hline 20 & GAMF & - & Visų apkrovų patikimumo koeficiento vidutinè reikšmé (dešimtainis skaičius) \\
\hline 21 & GAMFI & - & Ilgalaikių apkrovų patikimumo koeficiento vidutinė reikšmé (dešimtainis skaičius) \\
\hline 22 & AKOEF & - & Koeficientas, kuriuo apskaičiuotos ịtempimų reikšmès pakeičiamos MPa vienetais \\
\hline 23 & APLRIB & $m m$ & Ribinè trumpam laikui atsivérusių plyšiu pločio reikšme (dešimtainis skaičius) \\
\hline 24 & APLRII & $m m$ & Ribinè ilgam laikui atsivėrusių plyšių pločio reikšmė (dešimtainis skaičius) \\
\hline 25 & $M M A G 2$ & - & $\begin{array}{l}\text { Sveikasis skaičius: } M M A G 2=0 \text {, kai atsitiktiniai ekscentricitetai neịvertinami, ir } \\
M M A G 2=1 \text {, kai atsitiktiniai ekscentricitetai p̨vertinami }\end{array}$ \\
\hline
\end{tabular}


2 lentelè. Parametro $K$ reikšmès, kurios gali būti pateiktos panaudojant komandą ACTUSRPLOT

Table 2. Parameter $K$ values used by command ACTUSRPLOT

\begin{tabular}{|c|l|}
\hline $\mathbf{K}$ & Paaiškinimas \\
\hline \multicolumn{3}{|c|}{ Kai konstrukcija armuojama simetriškai } \\
\hline 4 & Vaizduojami konstrukcijos vienos zonos armavimo intensyvumai pirmaja linkme $\mathrm{cm}^{2} / \mathrm{m}$ \\
\hline 9 & Vaizduojami konstrukcijos vienos zonos armavimo intensyvumai antrąja linkme $\mathrm{cm}^{2} / \mathrm{m}$ \\
\hline \multicolumn{3}{|c|}{ Kai konstrukcija armuojama nesimetriškai } \\
\hline 4 & Vaizduojami konstrukcijos apatinès zonos (BOTTOM) armavimo intensyvumai pirmaja linkme $\mathrm{cm}^{2} / m$ \\
\hline 5 & Vaizduojami konstrukcijos viršutinès zonos (TOP) armavimo intensyvumai pirmaja linkme $\mathrm{cm}^{2} / \mathrm{m}^{2}$ \\
\hline 11 & Vaizduojami konstrukcijos apatinès zonos (BOTTOM) armavimo intensyvumai antraja linkme $\mathrm{cm}^{2} / \mathrm{m}$ \\
\hline 12 & Vaizduojami konstrukcijos viršutinès zonos (TOP) armavimo intensyvumai antraja linkme $\mathrm{cm}^{2} / \mathrm{m}$ \\
\hline
\end{tabular}

apkrovų variantu skaičius, armavimo linkmių kodas ir itempimų įrašų pavadinimai.

Armavimo intensyvumų gaubtinèms sudaryti taikoma programa COSMAX. Ši programa sukuria i̇raša, kuriame pateikiamos maksimalios armavimo intensyvumų reikšmès. Armavimo intensyvumų irašas sukuriamas taip, $\mathrm{kad} C O S M O S / M$ programos aplinkoje armavimo inten- syvumus būtu galima vaizduoti grafiškai. Su komanda ACTUSRPLOT nurodoma, kurios armatūros intensyvumus reikia pavaizduoti (2 lentelè), o vaizdo pobūdžiui pasirinkti taikoma komanda USRPLOT. Skaičiavimo rezultatı grafinio vaizdavimo pavyzdys pateikiamas paveiksle.

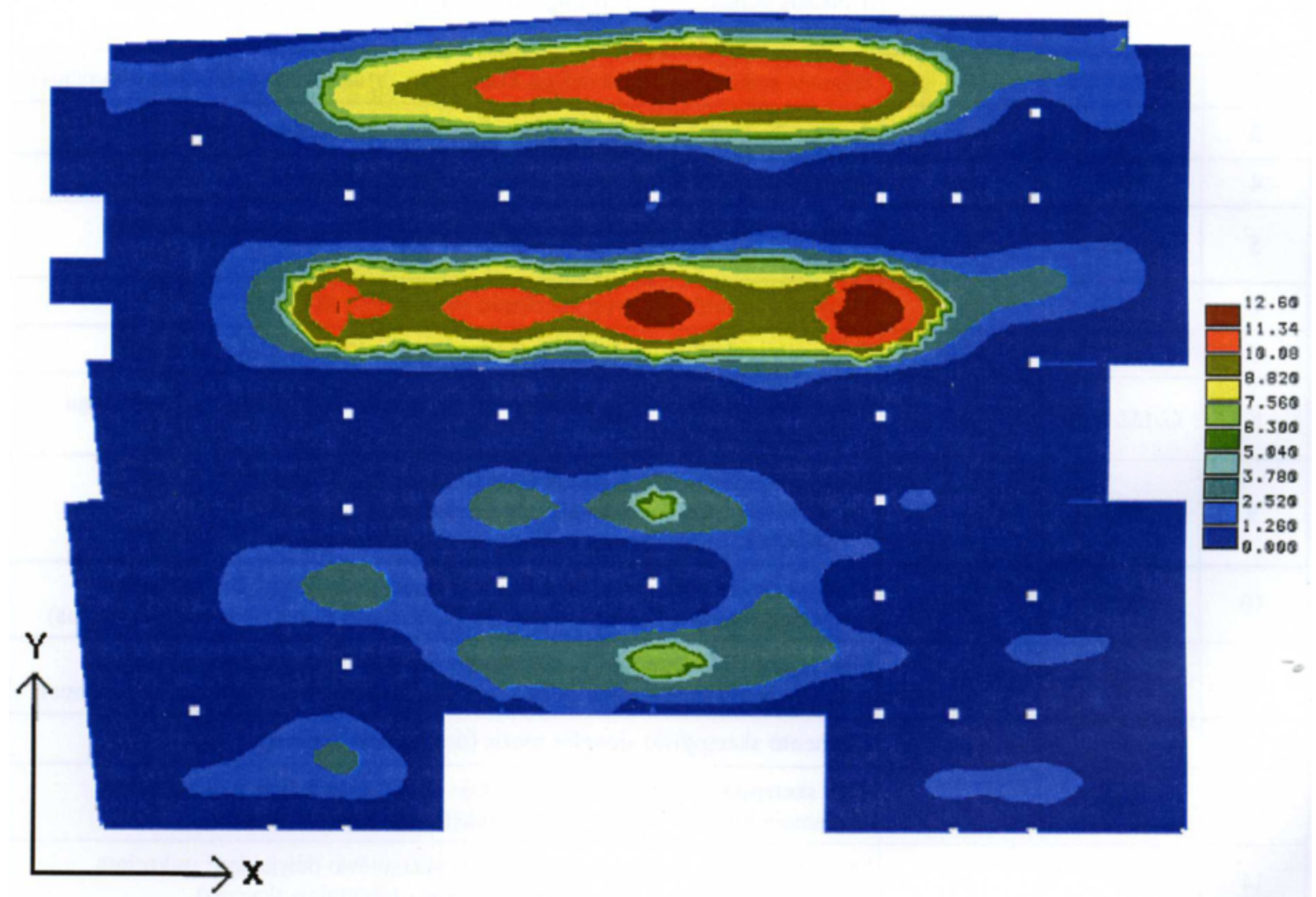

Plokštès apatinès zonos armavimo $Y$ linkme intensyvumai $\mathrm{cm}^{2} / m$ Intensities of $Y$ reinforcement located in the slab bottom zone $\mathrm{cm}^{2} / \mathrm{m}$ 
3. Kompiuterinès programos sijų armatūrai skaičiuoti ir jų panaudojimo technologija

Gelžbetoniniu siju išilginei ir skersinei armatūrai apskaičiuoti autorius sukūre kompiuterinių programy $B E A M$ ir COSBEAM kompleksą. Sijos skerspjūvis gali būti stačiakampis, dvitèjinis ir tèjinis su lentyna viršuje arba apačioje. Skaičiuojant armatūra juertinami lenkimo nukreiptos momentai apie lokalią $Z$ aši, lokalios $Y$ ašies linkme skersinès jègos ir sukimo momentai. Siju armatūros apskaičiavimo technologija yra tokia. Pradžioje su programa COSMOS/M sudaromas konstrukcijos kompiuterinis modelis ir galimi apkrovı variantai, kuriu bent viename pateikiamos tik nuolatinès ir ilgalaikès apkrovos. Kituose apkrovy variantuose, be laikinujų apkrovu, turi būti pateiktos ir nuolatinès bei ilgalai- kès apkrovos. Apkrovų reikšmès turi būti skaičiuojamosios. Atlikus analizę, COSMOS/M programos komandomis LISTLOG ir SMLIST sukuriami irą̌zu irašai. Sudaroma tiek ịrąžų ịrašų, kiek armatūros skaičiavimams reikia ivertinti apkrovu variantu. Tada su programa $B E$ $A M$ ịrąžu irašai modifikuojami, o su programa $C O S B E-$ $A M$ skaičiuojama armatūra.

Programa COSBEAM nuskaito modifikuotus irąžų irašus ir fiksuoto pavadinimo irašą INPUT.BEA, kuriame nurodomas irąžu irašų skaičius, siju skaičius, 3 lentelèje paaiškintu parametrų reikšmès ir irąžu reikšmių irašu pavadinimai.

Programa COSBEAM sukuria OUTPUT.BEA j̇rašą kuriame lengvai suprantama forma pateikiami siju išilginès ir skersinès armatūros skaičiavimo rezultatai.

3 lentelè. Parametrai INPUT.BEA iraše

Table 3. Parameters in INPUT.BEA file

\begin{tabular}{|c|c|c|c|}
\hline Eil. Nr. & Parametras & Dimensija & Paaiškinimas \\
\hline 1 & $K L A$ & - & $\begin{array}{l}\text { Sveikasis skaičius, rodantis išilginès armatūros klasę, pavyzdžiui, 3, jeigu } \\
\text { armatūros klasè } A-I I I\end{array}$ \\
\hline 2 & GAMASM & - & Išilginès armatūros darbo sąlygų koeficientų $\gamma_{s}$ sandauga (dešimtainis skaičius) \\
\hline 3 & GAM2 & - & Betono darbo sąlygu koeficientas $\gamma_{b 2}$ (dešimtainis skaičius) \\
\hline 4 & $D D 1$ & $m m$ & Išilginès armatūros strypų skersmuo (dešimtainis skaičius) \\
\hline 5 & $K L A S H$ & - & $\begin{array}{l}\text { Sveikasis skaičius, rodantis skersinès armatūros klasę, pavyzdžiui, 1, jeigu } \\
\text { armatūros klasè } A-I\end{array}$ \\
\hline 6 & $D D 2$ & $m m$ & Skersinès armatūros strypų skersmuo (dešimtainis skaičius) \\
\hline 7 & $A B$ & $M P a$ & Dešimtainis skaičius, rodantis betono gniuždymo klasę, pavyzdžiui, 22,5 \\
\hline 8 & $G A M A B M$ & - & $\begin{array}{l}\text { Betono visų darbo sąlygų koeficientų } \gamma_{b} \text {, išskyrus koeficientą } \gamma_{b 2} \text {, sandauga } \\
\text { (dešimtainis skaičius) }\end{array}$ \\
\hline 9 & $T E M$ & - & $\begin{array}{l}\text { Betono kietèjimo sąlygų parametras (dešimtainis skaičius): } \\
\text { - TEM }=0 \text {, jeigu betonas kietėja natūraliomis salygomis, } \\
\text { - TEM=1, jeigu betonas kaitinamas atmosferos slègyje }\end{array}$ \\
\hline 10 & $B F 1$ & $m$ & $\begin{array}{l}\text { Sijos skerspjūvio lentynos, esančios toje skerspjūvio dalyje, kuri nukreipta } \\
\text { teigiamaja lokalios } Y \text { ašies linkme, skaičiuojamasis plotis (dešimtainis skaičius) }\end{array}$ \\
\hline 11 & $B F$ & $m$ & $\begin{array}{l}\text { Sijos skerspjūvio lentynos, esančios toje skerspjūvio dalyje, kuri nukreipta } \\
\text { neigiamaja lokalios } Y \text { ašies linkme, skaičiuojamasis plotis (dešimtainis skaičius) }\end{array}$ \\
\hline 12 & $B$ & $m$ & Elemento skerspjūvio sienelès plotis (dešimtainis skaičius) \\
\hline 13 & $H F 1$ & $m$ & $\begin{array}{l}\text { Sijos skerspjūvio lentynos, esančios toje skerspjūvio dalyje, kuri nukreipta } \\
\text { teigiamaja lokalios } Y \text { ašies linkme, aukštis (dešimtainis skaičius) }\end{array}$ \\
\hline 14 & $H F$ & $m$ & $\begin{array}{l}\text { Sijos skerspjūvio lentynos, esančios toje skerspjūvio dalyje, kuri nukreipta } \\
\text { neigiamaja lokalios } Y \text { ašies linkme, aukštis (dešimtainis skaičius) }\end{array}$ \\
\hline 15 & $H$ & $m$ & Elemento skerspjūvio aukštis (dešimtainis skaičius) \\
\hline
\end{tabular}




\begin{tabular}{|c|c|c|c|}
\hline Eil. Nr. & Parametras & Dimensija & Paaiškinimas \\
\hline 16 & $A R 1$ & $m$ & $\begin{array}{l}\text { Išilginių strypu centro atstumas iki sijos skerspjūvio viršutinès arba apatinès briaunos } \\
\text { (dešimtainis skaičius) }\end{array}$ \\
\hline 17 & $A R 2$ & $m$ & $\begin{array}{l}\text { Šoniniu išilginių strypu centro atstumas iki sijos skerspjūvio artimiausios šoninès } \\
\text { briaunos (dešimtainis skaičius) }\end{array}$ \\
\hline 18 & $A A L$ & $m$ & Elemento ilgis (dešimtainis skaičius) \\
\hline 19 & GAMF & - & Visų apkrovy̨ patikimumo koeficiento vidutinè reikšmè (dešimtainis skaičius) \\
\hline 20 & GAMFI & - & Ilgalaikių apkrovų patikimumo koeficiento vidutinè reikšmè (dešimtainis skaičius) \\
\hline 21 & APLRIB & $m m$ & Ribinè trumpam laikui atsivèrusių plyšių pločio reikšmė (dešimtainis skaičius) \\
\hline 22 & APLRII & $m m$ & Ribinė ilgam laikui atsivèrusių plyšių pločio reikšmė (dešimtainis skaičius) \\
\hline 23 & $M M A G 1$ & - & $\begin{array}{l}\text { Koeficientas, kuriuo dauginamos įrąžos, taikomos siju armavimo skaičiavimui } \\
\text { (dešimtainis skaičius) }\end{array}$ \\
\hline 24 & $S F A C E$ & $m$ & Atramos centro atstumas iki jos krašto sijos pradžioje (dešimtainis skaičius) \\
\hline 25 & EFACE & $m$ & Atramos centro atstumas iki jos krašto sijos gale (dešimtainis skaičius) \\
\hline 26 & $D A S S S$ & - & $\begin{array}{l}\text { Koeficientas, kuriuo įrąžų reikšmès paverčiamos } M N \text { ir } M N m \text { vienetais (dešimtainis } \\
\text { skaičius) }\end{array}$ \\
\hline
\end{tabular}

\section{Kompiuterinès programos kolonų armatūrai skai- čiuoti ir jų panaudojimo technologija}

Naudojant autoriaus sukurtas kompiuterines programas COSREC, COSCIR ir COLUMN, apskaičiuojama gelžbetoniniu kolonų simetriška išilginè armatūra. Kolonos skerspjūvis gali būti stačiakampis (kvadratinis) arba apvalus. Skaičiuojant armatūrą, ivertinami lenkimo momentai apie lokalias $Y$ ir $Z$ ašis bei ašinès jègos.

Kolonų armatūros skaičiavimo technologija yra tokia pat, kaip sijų, tačiau irąžų reikšmiu irašai modifikuojami su programa COLUMN. Stačiakampio skerspjūvio kolonu armatūra skaičiuojama naudojant programą COSREC, o apvalaus skerspjūvio kolonu - COSCIR.
Programos COSREC ir COSCIR nuskaito modifikuotus irąžų irašus ir fiksuoto pavadinimo irašą INPUT.REC, kai kolonų skerspjūvis yra stačiakampis, ir INPUT.CIR, kai - apvalus. Šiame iraše nurodomas apkrovų varianty skaičius, parametrų reikšmès ir iražž reikšmių i̇rašų pavadinimai. INPUT.REC iraše pateikiamos KLA, GAMASM, GAM2, DMIN, DMAX, AB, GA$M A B M, T E M, B, H, A, A A L, E L Y, E L Z, D A S S S$ parametru reikšmès, o INPUT.CIR - KLA, GAMASM, GAM2, DMIN, DMAX, AB, GAMABM, TEM, YD, A, $A A L, E L, D A S S S$ reikšmès. Šiu parametru paaiškinimai pateikti 3 ir 4 lentelèse.

4 lentelè. Kai kurie parametrai INPUT.REC ir INPUT.CIR irašuose

Table 4. Some parameters in INPUT.REC and INPUT.CIR files

\begin{tabular}{|c|c|c|l|}
\hline Eil. Nr. & Parametras & Dimensija & \multicolumn{1}{|c|}{ Paaiškinimas } \\
\hline 1 & $D M I N$ & $m m$ & Išilginès armatūros strypų minimalus skersmuo (dešimtainis skaičius) \\
\hline 2 & $D M A X$ & $m m$ & Išilginès armatūros strypu maksimalus skersmuo (dešimtainis skaičius) \\
\hline 3 & $Y D$ & $m$ & Kolonos apvalaus skerspjūvio skersmuo (dešimtainis skaičius) \\
\hline 4 & $A$ & $m$ & $\begin{array}{l}\text { Išilginių strypų centro atstumas iki kolonos skerspjūvio krašto (dešimtainis } \\
\text { skaičius) }\end{array}$ \\
\hline 5 & $E L Y$ & - & $\begin{array}{l}\text { Koeficientas, kuriuo dauginamas stačiakampio skerspjūvio kolonos ilgis liaunumo } \\
\text { efektui įvertinti lokalios Y ašies linkme (dešimtainis skaičius) }\end{array}$ \\
\hline 6 & $E L Z$ & - & $\begin{array}{l}\text { Koeficientas, kuriuo dauginamas stačiakampio skerspjūvio kolonos ilgis liaunumo } \\
\text { efektui ịvertinti lokalios Z ašies linkme (dešimtainis skaičius) }\end{array}$ \\
\hline 7 & $E L$ & - & $\begin{array}{l}\text { Koeficientas, kuriuo dauginamas apvalaus skerspjūvio kolonos ilgis liaunumo } \\
\text { efektui įvertinti (dešimtainis skaičius) }\end{array}$ \\
\hline
\end{tabular}


Programa COSREC sukuria OUTPUT.REC irašą, kuriame pateikiami stačiakampio skerspjūvio kolonų armatūros skaičiavimo rezultatai. Analogiškai programa COSCIR sukuria OUTPUT.CIR ịraša, kuriame surašomi apvalaus skerspjūvio kolonų armatūros skaičiavimo rezultatai.

\section{Išvados}

Straipsnio autoriaus sukūrè gelžbetoninių konstrukcijų armatūros automatizuoto skaičiavimo pagal Lietuvoje galiojančias statybos normas ir taisykles pažangia technologiją, kuri išplečia galingos baigtiniu elementų metodo programos COSMOS $/ M$ galimybes. Ši technologija leidžia greitai ir patikimai apskaičiuoti sudètingu statiniu gelžbetonines konstrukcijas. Svarbi technologijos ypatybè yra ta, kad plokščių, sienų ir kevalu armatūros kompiuterinio skaičiavimo rezultatai pateikiami grafiškai. Programa STAAD.Pro tokios priemonès neturi iki šiol. Palyginti plačiai paplitusių Lietuvoje kompiuteriniu programu STAAD.Pro, LIRA-Windows ir programos COSMOS/M kartu su autoriaus sukurta armatūros skaičiavimo technologija galimybes, nustatyta, kad pastarasis programų kompleksas leidžia vartotoją dideliu ir sudètingu konstrukciju modeliavima, analize ir armatūros skaičiavimus atlikti greičiau net iki 20 ir daugiau kartu. Taikant šią technologija, nekyla problemų, norint teisingai sumodeliuoti bet kokio sudetingumo konstrukcijas ir jas apskaičiuoti.

\section{Literatūra}

1. STAAD.Pro 2001. Technical reference manual. Research Engineers International, Bristol, 2000.

2. НИИАСС Госкомградостроительства Украины. Программный комплекс ЛИРA-Windows. Руководство для пользователя. Том I-VIII. Украина. Киев, 1996-1997.
3. СНиП 2.03.01-84*. Бетонные и железобетонные конструкции. М.: Госстрой СССР, 1989. 80 с.

4. COSMOS/M. Finite element analysis system. Basic FEA System. User guide. Structural Research \& Analysis Corp., Los Angeles. 1995.

5. H. Tagnfors. Visualization of FE-data, interactively and on video // Advances in Engineering Software 30, 9-11, 1999 , p. $753-764$.

6. T. M. Wasfy, A. K. Noor. Visualization of CFD results in immersive virtual environments // Advances in Engineering Software, 32, 9, 2001, p. 717-730.

Iteikta 20010122

\section{TECHNOLOGY OF COMPUTATION OF REINFORCED CONCRETE STRUCTURES}

\section{A. Jurkša}

Su m m ary

The author has created a new technology for concrete beam, column, slab, wall and shell reinforcement computation according to the finite element program COSMOS $M$ analysis results and code of practice valid in Lithuania. A brief description of the technology is included in the article. Computer programmes COSARM and COSMAX were designed for slab, wall and shell reinforcement computation. Results can be visualized graphically. New computer programmes $B E A M$, COSBEAM, COLUMN, COSREC and COSCIR were created for beam and column reinforcement computation. The new technology extremely enlarged the possibilities of the powerful finite element program $\operatorname{COSMOS} / M$ and enabled to compute very complicated reinforced concrete structures.

Arvydas JURKŠA. PhD, Assoc Professor. Dept of Reinforced Concrete and Masonry Structures. Vilnius Gediminas Technical University (VGTU), Saulétekio al. 11, LT-2040 Vilnius, Lithuania. E-mail: gelz@st.vtu.lt

A graduate of Kaunas Polytechnic Institute (presently KTU) (1965, civil engineer). PhD (1971, engineering sciences), Assoc Professor (1976). Research visits: Birmingham University (UK, 1977), London City University (1978). Author of 83 articles and co-author of 2 manuals. Research interests: computer design, concrete and masonry structures, renovation and strengthening of buildings and structures. 